\title{
PENERAPAN PELAKSANAAN ASUHAN KEPERAWATAN PADA ANAK
}

Erta Iman Jelita Harefa/181101138

ertahrf08@gmail.com

\begin{abstract}
Abstrak
Latar belakang: Keperawatan anak adalah pelayanan profesional yang didasarkan pada ilmu keperawatan anak. Keperawatan anak berbentuk pelayanan secara bio-psiko-sosio dan spiritual yang komprehensif dalam keadaaan sehat maupun sakit dengan menggunakan pendekatan proses keperawatan.

Tujuan: Penulisan ini adalah untuk mengetahui dan memberi informasi tentang penerapan pelaksanaan asuhan keperawatan pada anak.

Metode: Penulisan ini menggunakan metode literature review dengan pendekatan jurnal atau artikel, buku dan $e$-book yang relevan dan akurat serta berfokus penerapan pelaksanaan asuhan keperawatan pada anak. Adapun jurnal atau artikel dan $e$-book yang digunakan pada literature review adalah jurnal atau artikel dan e-book yang didapatkan dengan menggunakan Google Scholar, Portal Garuda, dan Jurnal Keperawatan Indonesia.

Hasil: Berdasarkan hasil pencarian literatur didapatkan tahapan persiapan proses pelaksanaan asuhan keperawatan secara umum terdiri dari: pengkajian ulang terhadap klien, meninjau rencana keperawatan, mengorganisasi sumber daya, mencegah komplikasi dan mengimplementasi intervensi keperawatan.

Pembahasan: Dalam memberikan asuhan keperawatan anak secara profesional, perawat menggunakan pengetahuan teoritis yang akurat dan sesuai kebenaran dari berbagai ilmu yang terkait dengan ilmu keperawatan dan ilmu-ilmu dasar yang meliputi biologi, fisika, biomedik, perilaku dan sosial sebagai landasan dalam melakukan tahapan proses keperawatan.

Penutup: Dari hasil dan pembahasan yang telah dibahas di atas bahwa pelaksanaan asuhan keperawatan atau implementasi keperawatan pada anak sangat perlu diperhatikan dengan baik dan secara rinci setiap masalah status kesehatan yang dihadapi.
\end{abstract}

Kata kunci: penerapan, pelaksanaan, asuhan keperawatan anak 


\section{LATAR BELAKANG}

Keperawatan anak adalah pelayanan profesional yang didasarkan pada ilmu keperawatan anak. Keperawatan anak berbentuk pelayanan secara bio-psikososio dan spiritual yang komprehensif yang ditujukan pada anak usia 0-18 tahun dalam keadaaan sehat maupun sakit dengan menggunakan pendekatan proses keperawatan. pelayanan asuhan keperawatan yang diberikan melibatkan keluarga dan tenaga kesehatan lain yang sesuai dengan lingkup kewenangan dan tanggung jawabnya.

Dalam memberikan asuhan keperawatan secara profesional maka perawat perlu menerapkan dan meningkatkan proses pemberian asuhan keperawatan khususnya pada pelaksanaan asuhan atau implementasi keperawatan anak.

Implementasi keperawatan merupakan serangkaian kegiatan yang dilakukan oleh perawat untuk membantu pasien/klien dari masalah status kesehatan yang dihadapi. Dalam mencapai pelaksanaan asuhan atau implementasi keperawatan anak, perawat harus mempunyai keperawatan kognitif (intelektual), kemampuan dalam hubungan interpersonal dan keterampilan dalam melakukan tindakan.
Proses pelaksanaan asuhan keperawatan harus berpusat kepada kebutuhan pasien/klien khususnya pada anak, faktor-faktor lain yang mempengaruhi kebutuhan keperawatan, strategi implementasi keperawatan dan kegiatan komunikasi.

Pada saat implementasi keperawatan, perawat harus melaksanakan hasil dari rencana keperawatan yang dilihat dari diagnosa keperawatan. Sehingga asuhan keperawatan yang diberikan dapat tersusun dan terurut.

\section{TUJUAN}

Tujuan penulisan ini adalah untuk mengetahui dan memberi informasi tentang penerapan pelaksanaan asuhan keperawatan pada anak.

\section{METODE}

Penulisan ini menggunakan metode literature review dengan pendekatan jurnal atau artikel, buku dan e-book yang relevan dan akurat serta berfokus pada penerapan pelaksanaan asuhan keperawatan pada anak. Adapun jurnal atau artikel dan e-book yang digunakan pada literature review adalah jurnal atau artikel dan e-book yang didapatkan dengan menggunakan Google Scholar, 
Portal Garuda, dan Jurnal Keperawatan Indonesia.

\section{HASIL}

Berdasarkan hasil pencarian literatur di dapatkan tahapan persiapan proses pelaksanaan asuhan keperawatan secara umum sebagai berikut:

1. Pengkajian Ulang Terhadap Klien Langkah ini memberikan bantuan pada perawat dalam menentukan tindakan keperawatan yang masih sesuai denga kondisi klien.

2. Meninjau dan Merevisi Rencana Asuhan Keperawatan

Melakukan peninjauan rencana keperawatan dengan membandingkan data agar diagnosa keperawatan menjadi valid sehingga pelaksanaan asuhan keperawatan dapat telaksana dan tercapai.

3. Mengorganisasi Sumber Daya dan Pemberian Asuhan

Sumber daya suatu fasilitas mencakup peralatan dan personel yang memiliki keterampilan. Organisasi peralatan dan personel akan membuat perawatan klien menjadi tepat waktu, efisien, dan penuh keterampilan.

4. Mengantisipasi dan Mencegah Komplikasi
Dalam mengantisipasi dan mencegah komplikasi, perawat perlu mengenali resiko pada pasien/klien, menyesuaikan intervensi dengan situasi dan memulai tindakan pencegahan resiko.

5. Mengimplementasikan Intervensi Keperawatan

Implementasi intervensi keperawatan dilakukan berdasarkan keterampilan kognitif, keterampilan interpersonal, dan keterampilan psikomotor.

Adapun macam-macam implementasi keperawatan atau pelaksanaan asuhan keperawatan terdiri dari:

- Impelementasi keperawatan independen adalah tindakan yang dilakukan perawat yang tidak membutuhkan arahan dari profesional kesehatan lainnya.

- Implementasi keperawatan dependen adalah tindakan yang dilakukan perawat berdasarkan arahan dari dokter atau profesional kesehatan lainnya.

- Implementasi keperawatan kolaboratif adalah tindakan yang dilakukan perawat berdasarkan adanya gabungan pengetahuan, keterampilan, dan keahlian dari berbagai profesional kesehatan lainnya. 


\section{PEMBAHASAN}

Keperawatan anak merupakan

keyakinan atau pandangan yang dimiliki perawat dalam memberikan pelayanan keperawatan pada anak yang berfokus pada keluarga, pencegahan terhadap trauma, dan manajemen kasus. Dalam dunia keperawatan anak, perawat perlu memahami dan mengingat adanya beberapa prinsip yang berbeda dalam penerapan asuhan dikarenakan anak bukan miniatur orang dewasa tetapi sebagai individu yang unik (Hidayat, 2005).

Dalam memberikan asuhan keperawatan anak secara profesional, perawat menggunakan pengetahuan teoritis yang akurat dan sesuai kebenaran dari berbagai ilmu yang terkait dengan ilmu keperawatan dan ilmu-ilmu dasar yang meliputi biologi, fisika, biomedik, perilaku dan sosial sebagai landasan dalam melakukan tahapan proses keperawatan.

Terkait pentingnya pemberian asuhan keperawatan profesional, maka seorang perawat harus menunjukkan kemampuan keterampilan dan pengetahuan yang berkembang secara terus-menerus.

Dalam mengetahui perkembangan keterampilan dari seorang perawat dapat dilihat dari cara pemberian asuhan keperawatan atau implementasi keperawatan pada pasien/klien.

Impelementasi keperawatan merupakan pelaksanaan rencana tindakan keperawatan oleh perawat dan pasien serta pengelolaan dan perwujudan dari rencana keperawatan yang telah disusun pada tahap perencanaan (Riyadi, 2010).

\section{PENUTUP}

Dari hasil dan pembahasan yang telah dibahas di atas bahwa pelaksanaan asuhan keperawatan atau implementasi keperawatan pada anak sangat perlu diperhatikan dengan baik dan secara rinci setiap masalah status kesehatan yang dihadapi. Dalam pemberian asuhan keperawatan pada anak secara langsung harus perlu dilihat secara detail dan rinci sehingga asuhan keperawatan yang diberikan dapat memberikan peningkatan mutu pelayanan kesehatan khususnya pada anak.

\section{REFERENSI}

Asmadi. (2008). Konsep Dasar Keperawatan. Jakarta: EGC.

Budiono. (2016). Konsep Dasar Keperawatan. Jakarta: Pusdik SDM Kesehatan. 
Efendi, Ferry. (2008). Pendidikan

Dalam Keperawatan. Jakarta:

Salemba Medika.

Hidayat, A. Aziz Alimul. (2005). Pengantar Ilmu Keperawatan Anak, Edisi 1. Jakarta: Salemba Medika.

Hidayat, A. Aziz Alimul. (2005). Pengantar Ilmu Keperawatan Anak, Edisi 2. Jakarta: Salemba Medika.

Hidayat, A. Aziz Alimul. (2008). Pengantar Konsep Dasar Keperawatan. Jakarta: Salemba Medika.

Nurlaila, Utami, W., W. Cahyani T. (2018). Buku Ajar Keperawatan Anak. Yogyakarta: LeutikaPrio.

Potter \& Perry. (2005). Buku Ajar Fundamental Keperawatan: Konsep, Proses dan Praktik, Edisi 4 Vol. 1. Jakarta: EGC.

Priharjo, Robert. (2008). Konsep \& Perspektif Praktik Keperawatan Profesional. Jakarta: EGC.

Rosidah, A. (2012). Persepsi Orang Tentang Perilaku Caring Perawatan Pada Pelaksanaan Asuhan Keperawatan di Ruang Rawat Inap Anak RSUD Serang
Tahun 2011, Jurnal FKIK, 2234.

Simamora, R. H. (2008). Peran Manajer Dalam Pembinaan Etika Perawat Pelaksana Dalam Peningkatan Kualitas Pelayanan Asuhan Keperawatan. Jurnal IKESMA.

Simamora, R. H. (2009). Dokumentasi Proses Keperawatan. Jember University Press.

Simamora, R. H. (2010). Komunikasi Dalam Keperawatan. Jember University Press.

Sumijatun. (2010). Konsep Dasar Мепији Keperawatan Profesional. Jakarta: Trans Info Medika.

Supartini, Yupi. (2004). Buku Ajar Konsep Dasar Keperawatan Anak. Jakarta: EGC.

Yugistyowati, A., \& Santoso, S. (2018). Pengetahuan Perawat Tentang Family Centered-Care Dengan Sikap Dalam Pemberian Asuhan Keperawatan di Ruang Rawat Inap Anak. Jurnal Keperawatan Respati. Yogyakarta, 39-44.

Yuliastati, Nining. (2016). Keperawatan Anak. Jakarta: Kemenkes RI. 